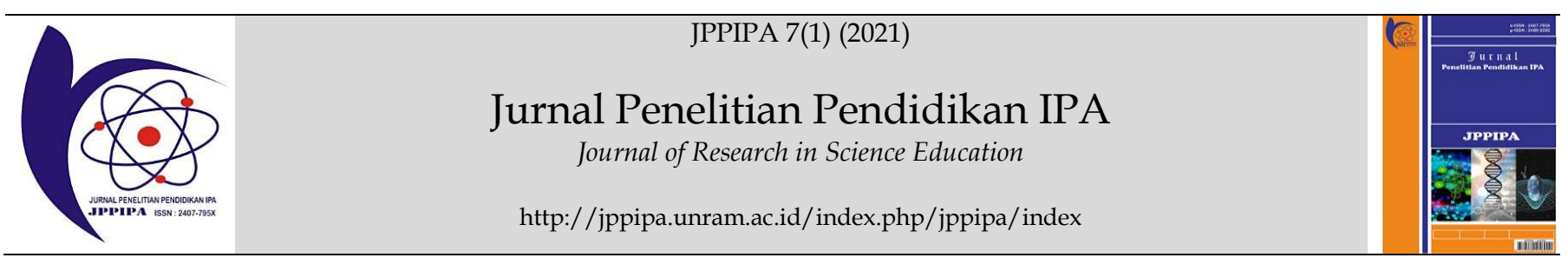

\title{
Literature Study: Improving Understanding of Science Concepts Using Science Comics for Elementary School Students
}

\author{
Nia Maulidah $^{1 *}$, Fitria Wulandari² \\ 1 Elementary School Teacher Education, Faculty of Psychology and Educational Sciences, Muhammadiyah University of Sidoarjo, \\ Indonesia \\ 2 Elementary School Teacher Education, Faculty of Psychology and Educational Sciences, Muhammadiyah University of Sidoarjo, \\ Indonesia
}

DOI: $10.29303 /$ jppipa.v7i1.509

\section{Article Info}

Received : November 23th, 2020

Revised : December 30th, 2020

Accepted: January $8^{\text {th }}, 2021$

\begin{abstract}
This study aims to determine the increase in understanding of elementary school science concepts using media science comics. The method used in this research is qualitative research with data collection techniques, namely literature studies. The data collection technique used is by collecting and studying data on various research results from journals, theses, scientific articles, and relevant journals. The data that has been obtained, analyzed, and studied in-depth, systematically, and critically are then described in a narrative. Based on the results of research, the literature study states that the use of media science comics can improve understanding of the concept of science in elementary schools. From the results of the research analysis showed that the results of the pretest scores of students had low concept understanding in the experimental class and the control class. After being given treatment, the results of the posttest scores showed a significant increase in the experimental class.
\end{abstract}

Keywords: Media science comics; understanding of science concepts; elementary school

Citation: Maulidah, N., \& Wulandari, F. (2021). Literature Study: Improving Understanding of Science Concepts Using Science Comics for Elementary School Students. Jurnal Penelitian Pendidikan IPA. 7(1). 80-86. doi: https://doi.org/10.29303/ippipa.v7i1.509

\section{Introduction}

Understanding the concept is important in learning science learning. Understanding concepts that are misunderstood by students will result in students having a wrong understanding. Students can be said to understand the concept if the concept has been stored in the mind of the student so that students can make an example of a concept and distinguish examples from non-examples (Jamuri, et al., 2015). A number of elementary school students only memorize the material taught by the teacher, not understanding concepts, especially in science subjects. In understanding the concept of science, mistakes often occur because the teacher only invites students to memorize the material given (Susilawati, et al., 2021). Students should not memorize but understand the concepts being learned. The concept given by the teacher cannot be understood by students. Teachers tend to invite students to memorize concepts instead of understanding concepts so that students absorb these concepts (Faradilla, et al., 2016). For this reason, teachers must be able to make students easier to improve understanding of the concepts being taught by fostering motivation in advance to students, so that students can understand the material taught by the teacher (Khairunnisak, 2015).

In the teaching and learning process so that students can understand the concept correctly the teacher needs learning media. The learning media used in learning activities also contribute to attracting student interest in learning so that it can increase student understanding (Doyan, et al., 2021). According 
to (Arsyad, 2004) states that learning media can help students improve understanding, help to learn more the interestingly, make it easier for students to understand material and condense information. According to (Wahyu, et al., 2020) states that the use of learning media can change the learning paradigm, because it can increase students' self-confidence to be more participatory, collaborative, and interactive so that learning is more meaningful. One of the learning media that can be used as learning media is comics. Comics can improve understanding and strengthen students' memories, because visual displays are more attractive than just verbal displays (Wati, 2016).

By using comic learning media, it is hoped that it can provide new nuances and increase students' understanding because it involves students directly in learning. Comics can be used as a medium in learning, especially in science subjects. The comic used in science learning is science comics. Science comics in science learning contains material related to the real world and uses the language used by students every day. Science comic media in science learning explains stories that can tell an event or events that occur around them through observations or activities that are experienced by themselves (Khairi, 2016).

According to (Maslichah, 2016) said that the design in Science Comics is in accordance with the characteristics of students, can be used in the KTSP and K-13 Curriculum, equipped with scientific observations of the surrounding environment so that students understand the concept of Science, arranged in simple language so that it is easy to understand, The images and backgrounds in science comics are adjusted by students and their surroundings. Thus, the media science comics can be used in learning because the media science comics are in accordance with the characteristics of students, are easy to understand, and can improve students' understanding of science concepts.

Based on the above background, the researcher is interested in analyzing and examining more deeply the "Literature Study of Improving Understanding of Science Concepts by Using Science Comics in Elementary Schools".

\section{Method}

This study uses qualitative research methods with data collection techniques, namely literature studies. (Sarwono, 2006) states that the literature study is the study of data from various reference books and the results of previous research that are relevant to the research in order to obtain a theoretical basis for the problem to be examined. Data collection techniques are by collecting and studying data on various research results from journals, theses, scientific articles, and relevant journals. Thesis data sources, scientific articles, and journals used in this research are about increasing concept understanding by using science comics at Elementary Schools. In this research, the study of relevant journals, articles, theses is used to find out how to increase understanding of the concept of science by using the science comic media in elementary schools. The journals used in this research are as follows:

Table 1. Journal Used in research

\begin{tabular}{ll}
\hline No. & Journal Name \\
\hline 1. & Journal of Kalimaya \\
2. & Thesis of Universitas Islam Negeri Syarif \\
& Hidayatullah Jakarta \\
3. Journal of Procedia Social and Behavioral Sciences \\
4. Journal of Pembelajaran dan Biologi \\
5. Journal of Pedagogic Development \\
6. $\quad$ Journal of Nirmana \\
\hline
\end{tabular}

The data analysis technique used in this study is the Miles and Huberman model. According to Miles and Huberman in (Sugiyono, 2010), data analysis activities include data reduction, data presentation and drawing conclusions. In this study, data collection was obtained from theses, scientific articles, and journals that were in accordance with research to improve understanding of science concepts using science comics of elementary school students, then the data obtained were analyzed and studied in depth, systematically, and critically which were then described in a comprehensive manner narrative.

The data used to measure the understanding of the science concept in this study are as follows:

Table 2. The data used in the study

\begin{tabular}{|c|c|c|}
\hline Name & The Result & Conclusion \\
\hline Faradilla & $\begin{array}{l}\text { It is known that the value of the pretest, posttest control class } \\
\text { obtained 40.74, which is an increase of only } 9.81 \text { points. } \\
\text { Meanwhile, the experimental class posttest in the experimental } \\
\text { class increased in value by } 32.04 \text {. The value of the experimental } \\
\text { class increased } 3 x \text { compared to the control class. }\end{array}$ & $\begin{array}{l}\text { There is an increase in students' } \\
\text { understanding of concepts in the } \\
\text { experimental class when using } \\
\text { science comic media. }\end{array}$ \\
\hline Parsaulian & $\begin{array}{l}\text { Results in the control class }(\bar{X} \pm S B) 64,776 \pm 15,941 \text { was } \\
\text { significantly higher than the control class, namely }(\overline{\bar{X}} \pm S B) \text { of } 47,771 \\
\pm 14,319 \text { (thitung }=6,873 ; \mathrm{P}=0,000) \text {. It can be concluded that the }\end{array}$ & $\begin{array}{l}\text { There is an increase in understanding } \\
\text { of using science comic strips for } \\
\text { elementary students. }\end{array}$ \\
\hline
\end{tabular}




\begin{tabular}{|c|c|c|}
\hline Name & The Result & Conclusion \\
\hline \multirow{3}{*}{ Pasaribu } & understanding of the experimental class students was $35.59 \%$ & \multirow{3}{*}{$\begin{array}{l}\text { There is an increase in understanding } \\
\text { the concept of science by using comic } \\
\text { media. }\end{array}$} \\
\hline & $\begin{array}{l}\text { The pretest value of the experimental class and the control class at } \\
\text { a significant level of } 0.05 \text {, fulfills the criteria }-t_{\text {tabel }} \leq t_{\text {hitung }} \leq t_{\text {tabel, }} \\
-1,67 \leq-0,93 \leq 1,67 \text {. This means that the hypothesis Ho is accepted } \\
\text { and Ha is rejected. From the calculation, the value of } t \text { count or } \\
\text { equal to } 2.61 \text { and } t \text { table or equal to } 1.67 \text {. This fulfills the criteria }\end{array}$ & \\
\hline & $\begin{array}{l}t_{\text {hitung }} t_{\text {tabel }} \text { price. Thus } H_{o} \text { is rejected and } H_{a} \text { is accepted at the } 0.05 \\
\text { level. }\end{array}$ & \\
\hline
\end{tabular}

\section{Results and Discussion}

This analysis is used to measure the improvement in understanding the concept of science by using the media science comics in elementary schools. Based on the analysis of the results of the research conducted by (Faradilla et al., 2016) students used in the study were class III students with a population of 54 students. The measuring instrument used is a test. The pretest and posttest gain data analysis was used to measure the increase in students' understanding of concepts. The results of the analysis of the increase in students' conceptual understanding can be seen in Table and 2 as follows:

Table 3. The result of the analysis of increased understanding of concept of the experimental class

\begin{tabular}{|c|c|c|c|c|c|}
\hline Statistics & $\operatorname{Max}$ & Min & Mean & Gain & Exp. \\
\hline Pretest & 70 & 0 & 33,98 & \multirow[t]{2}{*}{0,54} & \multirow{2}{*}{ Medium } \\
\hline Posttest & 100 & 0 & 65,93 & & \\
\hline
\end{tabular}

Table 4. The result of the analysis of increased understanding of concept of the control class

\begin{tabular}{llllll}
\hline Statistics & Max & Min & Mean & Gain & Exp. \\
\hline Pretest & 70 & 0 & 30,92 & \multirow{2}{*}{0,21} & \multirow{2}{*}{ Low } \\
\hline Posttest & 95 & 0 & 40,74 & & \\
\hline
\end{tabular}

The results showed that when the pretest was carried out, there was no difference in understanding between the experimental class and the control class. The average value is only three points difference, which indicates that students' understanding of the concept is not different. So it can be concluded that there is a similarity in the understanding of students between the experimental and control classes. After being given treatment using comic media, the postest score in the experimental class increased threefold, namely by 32.04. Meanwhile, the post-test score in the control class only increased 9.81 points.

Judging from the results of the analysis, the experimental class obtained an average value from 33.89 to 65.93 , which means that understanding has increased. Meanwhile, the average score in the control class was from 30.92 to 40.74 , which means it increased slightly. Judging by the gain criteria, the experimental class obtained an average gain of 0.54 in the medium category. While the gain in the control class obtained an average value of 0.21 in the low category.

The results of increasing students' understanding of science concepts in the experimental class and the control class can be seen in Figures 1 and 2 below:

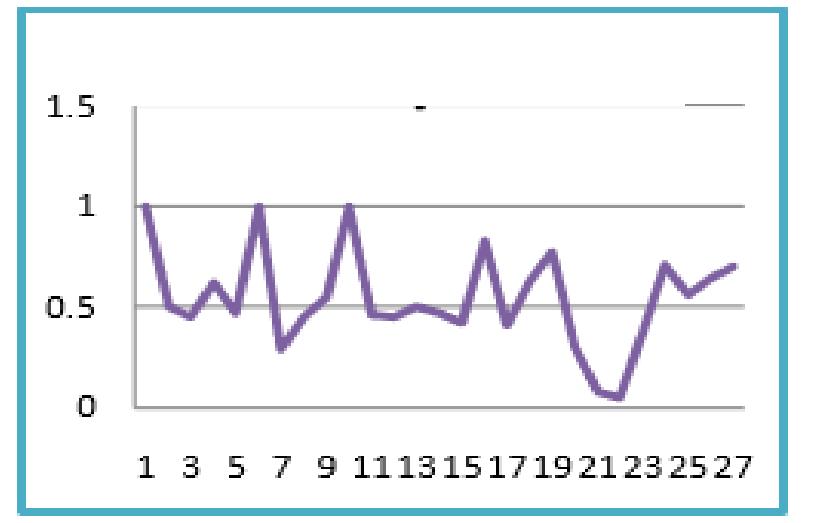

Figure 1. The result of the analysis of increasing understanding of science concept in the experimental class

From the results of Figure 1 shows that in the experimental class almost all straight lines go up to gain with high interpretation. This means that almost all students in the experimental class get an increase in the gain value. The increase in student understanding is due to the existence of science comic media that is applied in learning so that students understand the concepts given by the teacher.

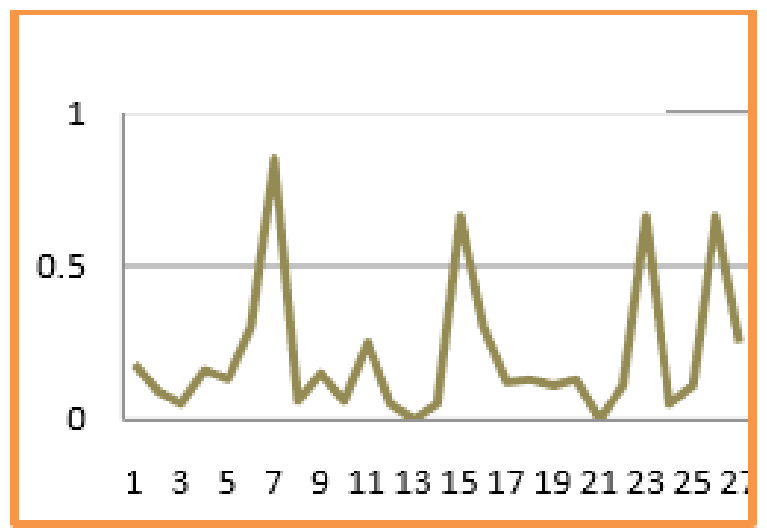

Figure 2. The result of the analysis of increasing understanding of science concept in the control class 
From the results of Figure 2, it shows that a straight line up indicates that the interpretation of the gain in the category is heading low. In the control class there is only one student gain score in the high category and the other students with low gain scores. This means that the control class does not show an increase in students' conceptual understanding.

Based on the results of this analysis, it can be stated that there are differences in the understanding of students after being given treatment between the experimental class and the control class. From the above research, it can be concluded that the science comic media can improve the understanding of the science concept of class III students. This is in accordance with the results of research conducted by (Mudaim, 2015) which states that comic media can make it easier for natural students to understand the concepts being studied, with the characters in comics making students interested in reading them so that learning outcomes increase because students understand the concept of the material taught. This is also supported by research conducted by (Oruc \& Teymuroglu, 2011) which states that there are significant differences in the pretest and posttest scores in the experimental group using cartoon images in learning. The existence of cartoon pictures in learning can have a positive effect on students in understanding the material because learning is not monotonous.

Another study was conducted by (Parsaulian, 2017) with a population of class IV students totaling 150 students. This research hypothesis testing was carried out using the $t$ test at the significant level $\alpha=0.05$. The results of the analysis of the increase in students' conceptual understanding in the experimental class and control class are as follows:

Table 5. The result of the analysis of increased understanding of concept

\begin{tabular}{llllll}
\hline Statistics & $\bar{X}$ & SB & $\mathrm{t}_{\text {count }}$ & $\mathrm{P}$ & $\begin{array}{l}\text { Conclu- } \\
\text { tion }\end{array}$ \\
\cline { 1 - 3 } Eksperiment & 64,776 & 15,941 & 6,873 & 0,000 & $\begin{array}{l}\mathrm{H}_{\mathrm{a}} \\
\text { accepted }\end{array}$ \\
\hline Control & 47,771 & 14,319 & & & accep
\end{tabular}

The results showed that the control class had a higher average value than the control class. The table results show that in the experimental class $(\bar{X} \pm \mathrm{SB})$ $64,776 \pm 15,941$ was significantly higher than the control class, namely $(\bar{X} \pm \mathrm{SB})$ sebesar $47,771 \pm 14,319$ (thitung $=$ $6,873 ; \mathrm{P}=0,000)$. It can be concluded that the understanding of the experimental class students was $35.59 \%$ higher than the control class.

The results of increasing students' understanding of science concepts in the experimental class and the control class can be seen in the following figure:

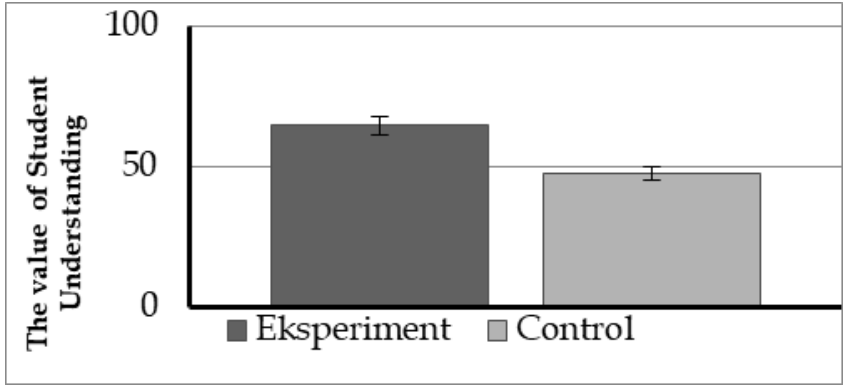

Figure 3. The value of student Understanding

From the picture above shows that the students' scores in the experimental class by applying science comic media in learning were compared to the control class who did not use science comic media in learning. This means that the use of science comics media can improve students' conceptual understanding. From the results of the research above, it can be concluded that the science comic media is the right media to use in science learning because science comics learning media can make it easier for students to understand the concepts in science learning material so that students' understanding of science concepts increases.

This is also in line with research conducted by (Shaltout, 2016) which states that comics have the potential to be very effective for use in learning. With an interesting picture in the dialogue of students, it makes it easier for students to understand the concepts being learned. This is also supported by research conducted by (Dalacosta, et al., 2011) who concluded that the use of comics is very effective because it can attract attention quickly and directly to the point so as to improve students' conceptual understanding, especially in elementary schools where misconceptions often occur in understanding science concepts.

Another research was also conducted by (Pasaribu, 2014), with a total sample of 60 students. To find out the results of the hypothesis, hypothesis testing can be done using the $t$ test formula. The results of the analysis of the increase in students' conceptual understanding in the experimental class and control class are seen from Table 6 and 7 as follows:

Table 6. The result of the pretest analysis of increased understanding of the concept

\begin{tabular}{|c|c|c|c|c|c|c|}
\hline Statistics & $\mathrm{N}$ & $\overline{\bar{X}}$ & $S$ & $t_{\text {count }}$ & $t_{\text {table }}$ & Conclution \\
\hline $\begin{array}{l}\text { Eksperi- } \\
\text { ment }\end{array}$ & 30 & 56,5 & 16,14 & \multirow[t]{2}{*}{$-0,93$} & \multirow[t]{2}{*}{1,67} & \multirow{2}{*}{$\begin{array}{l}\mathrm{H}_{\mathrm{o}} \\
\text { accepted }\end{array}$} \\
\hline Control & 30 & 60,1 & 14,29 & & & \\
\hline
\end{tabular}

Table 7. The result of the posttest analysis of increased understanding of the concept

\begin{tabular}{|c|c|c|c|c|c|c|}
\hline Statistics & $\mathrm{N}$ & $\overline{\bar{X}}$ & $S$ & $\mathrm{t}_{\text {count }}$ & $t_{\text {table }}$ & Conclution \\
\hline $\begin{array}{l}\text { Eksperi- } \\
\text { ment }\end{array}$ & 30 & 85,5 & 14,4 & \multirow[t]{2}{*}{2,61} & \multirow[t]{2}{*}{1,67} & \multirow{2}{*}{$\begin{array}{l}\mathrm{H}_{\mathrm{o}} \\
\text { rejected }\end{array}$} \\
\hline Control & 30 & 73,6 & 16,4 & & & \\
\hline
\end{tabular}


From the table of the results of the calculation of the hypothesis test above, it can be said that the pretest value of the experimental class and control class at the significant level of 0.05 , fulfills the criteria $-t_{\text {tabel }} \leq t_{\text {hitung }}$ $\leq t_{\text {tabel }}$ namely $-1,67 \leq-0,93 \leq 1,67$. This means that the hypothesis $\mathrm{H}_{\mathrm{o}}$ is accepted and $\mathrm{H}_{\mathrm{a}}$ is rejected. So, it can be concluded that there is no significant difference between the pretest results of the experimental class and the control class. From the calculation, the value of $t$ count or equal to 2.61 and $t$ table or equal to 1.67. This fulfills the criteria $t_{\text {hitung }} t_{\text {tabel }}$ price. Thus $\mathrm{H}_{\mathrm{o}}$ is rejected and $\mathrm{H}_{\mathrm{a}}$ is accepted at the 0.05 level. This shows that there is an increase in students' conceptual understanding using comic media. This is evidenced by the posttest results show that the average learning outcomes of the experimental class students are higher than the average learning outcomes of the control class.

The results of increasing students' understanding of science concepts in the experimental class and the control class can be seen in the following figure:

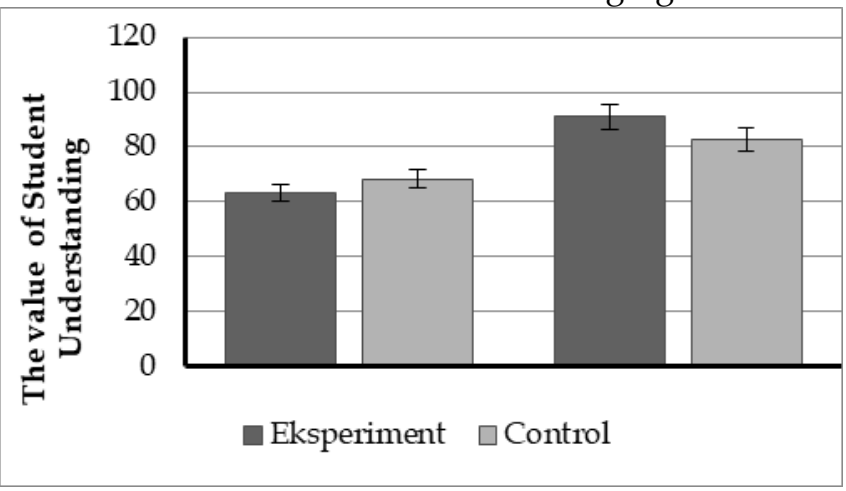

Figure 4. The value of student Understanding

From the results of the research above, it can be concluded that the science comic media is the right media to be used in science learning because science comics learning media can make it easier for students to understand the concepts in science learning materials so that students' understanding of the science concepts increases. This is also in line with research conducted by (Piaw, 2012) which states that comics can improve students' understanding because they trigger the mind to think about the topic being discussed, increase reading resistance, and improve the ability to understand information.

From the results of the research analysis above shows that the pretest scores of students have a low understanding of the concept in the experimental class and control class. That is, several studies that have been done, shows that the understanding that students have in the experimental class and the control class is the same or there is no difference. In the control class, it shows that students do not understand the material that has been given in learning. While the experimental class was given treatment using media science comics in learning, students looked active and were able to understand the material provided during learning. This is in accordance with the opinion (Waluyanto, 2005) which states that comics are a combination of writing and images arranged in a storyline so that information is easier to understand. So, it can be said that when given the treatment there is a different understanding between the experimental class and the control class.

After being given treatment in the experimental class using science comics in science learning, it shows that there is an increase in students' understanding of the science concept and when learning students can answer questions given by the teacher. Besides that, students can also explain and conclude the material that has been given by the teacher. So that learning objectives can be achieved. Meanwhile, the control class did not show a significant increase. This is in accordance with (Akbar, 2017), which states that the function of learning media is to attract students' attention, create feelings of pleasure, and help students to understand and remember learning material. This is also supported by research (Andriyani \& Kusmariyatni, 2019) which states that the experimental group obtained a higher average value of learning outcomes compared to the control group. This is due to the existence of science comic media which can improve student learning outcomes. Examples of science comics in improving elementary school students' understanding of science concepts are as follows:

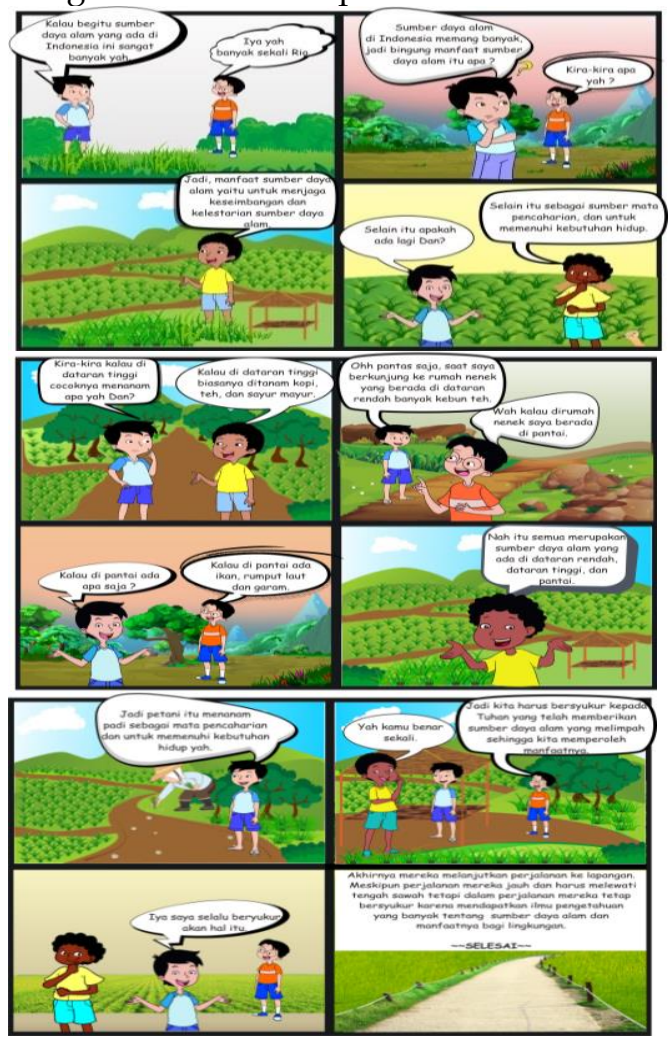

Figure 5. Example of science comic. 


\section{Conclusion}

Based on the literature study, it can be concluded that the use of science comic media can improve the understanding of science concepts in elementary schools. From the results of the research analysis showed that the results of the pretest scores of students had low concept understanding in the experimental class and the control class. After being given treatment, the results of the posttest scores showed a significant increase in the experimental class.

\section{Acknowledgments}

Thank you to the thesis supervisor who has guided this literature study to completion. Thank you to the big family of the University of Muhammadiyah Sidoarjo who have provided the opportunity to complete the thesis well. Thank you to the University of Mataram for facilitating the production of this article. Thank you also to both parents, siblings, and friends in arms for the prayers, cooperation, and support

\section{References}

Akbar, S. (2017). Instrumen Perangkat Pembelajaran. Bandung: PT. Remaja Rosdakarya.

Andriyani, F., \& Kusmariyatni, N. N. (2019). Pengaruh Media Komik Berwarna terhadap Hasil Belajar IPA Siswa. Jurnal Pedagogi Dan Pembelajaran, 2(3), 341-350. Retrieved from https://ejournal.undiksha.ac.id/index.php/JP2/ article/view/19282/11411

Arsyad, A. (2004). Media Pembelajaran. Jakarta: Raja Grafindo Persada.

Dalacosta, K., Paparrigopoulou-kamariotaki, M., \& Pavlatou, E. A. (2011). Can we assess pupil's science knowledge with animated cartoons ? Procedia Social and Behavioral Sciences, 15, 32723276.

https:// doi.org/10.1016/j.sbspro.2011.04.284

Doyan, A., Susilawati, \& Hardiyansyah, A. (2021). Development of Natural Science Learning Tools with Guided Inquiry Model Assisted by Real Media to Improve Students ' Scientific Creativity and Science Process Skills. Journal of Research in Science Education, 7(1), 15-20. https://doi.org/10.29303/jppipa.v7i1.485

Faradilla, D. Y., Wuryastuti, S., \& Susanti, L. (2016). Pengaruh Media Komik Sains terhadap Pemahaman Peserta didik pada Pembelajaran IPA Konsep Energi Gerak Peserta didik Kelas III. Kalimaya, 4(2), 1-11. Retrieved from http://antologi.upi.edu/file/IPA_DESTIKAYUSI
ANAFARADILLA_1203404.pdf

Jamuri, Kosim, \& Doyan, A. (2015). Pengaruh Model Pembelajaran Kooperatif STAD Berbasis Multimedia Interaktif Terhadap Penguasaan Konsep Siswa pada Materi Termodinamika. Jurnal Penelitian Pendidikan IPA (JPPIPA), 1(1), 123-134. Retrieved from https://jppipa.unram.ac.id/index.php/jppipa/ar ticle/download/11/11

Khairi, A. (2016). Pengembangan Media Komik Berbasis Karakter untuk Siswa Sekolah Dasar. Jurnal PPKn \& Hukum, 11(1), 98-110. Retrieved from

https://pbpp.ejournal.unri.ac.id/index.php/JPB/ article/download/3658/3564

Khairunnisak. (2015). Peningkatan Pemahaman Konsep dan Motivasi Belajar Siswa Melalui Simulasi Physic Education Technology (PhET). Jurnal Penelitian Pendidikan IPA (JPPIPA), 4(1), 7-12. https://doi.org/https://doi.org/10.29303/jppipa .$v 4 \mathrm{i} 2.109$

Maslichah, A. (2016). Pengembangan Media Pembelajaran Komik Sains berbasis Inkuiri terbimbing untuk meningkatkan Pemahaman Konsep Materi Gaya dan Perubahannya Kelas V MI Darul Muwahhidin Mojokerto (Universitas Islam Negeri (UIN) Maulana Malik Ibrahim Malang). Retrieved from http:/ / etheses.uin-

malang.ac.id/4905/1/12140029.pdf

Mudaim, R. S. (2015). Pengaruh Media Komik terhadap Hasil Belajar PKn Peserta didik Kelas III MI. Darul Muqinin (Universitas Islam Negeri Syarif Hidayatullah Jakarta). Retrieved from http:/ / repository.uinjkt.ac.id/dspace/bitstream/ 123456789/29277/3/Ratna Sarifah Mudaim FITK.pdf

Oruc, S., \& Teymuroglu, B. (2011). The effects of using cartoon in teaching social sciences on attitudes of students against to social science course. Procedia Social and Behavioral Sciences, 15, 3211-3215. https://doi.org/10.1016/j.sbspro.2011.04.273

Parsaulian, R. (2017). Pengaruh Penggunaan Komik IPA Sains terhadap Hasil Belajar Kognitif Siswa SD pada Materi Rangka Manusia. Jurnal Pembelajaran Dan Biologi Nukleus, 3(1), 47-53. Retrieved from http://jurnal.ulb.ac.id/index.php/nukleus/articl e/download/1203/1188

Pasaribu, A. N. A. (2014). Pengaruh PenggunaanMedia Komik terhadap Hasil Belajar IPA pada Konsep Kondisi Lingkungan terhadap Kesehatan (Universitas Islam Negeri Syarif Hidayatullah Jakarta). Retrieved from http:/ / repository.uinjkt.ac.id/dspace/bitstream/ 123456789/24923/1/Annisa Nurul Aini 
Pasaribu.pdf

Piaw, Y. C. (2012). Using content-based humorous cartoons in learning materials to improve students' reading rate, comprehension and motivation : It is a wrong technique ? Procedia Social and Behavioral Sciences, 64, 352-361. https://doi.org/10.1016/j.sbspro.2012.11.042

Sarwono, J. (2006). Metode Penelitian Kuantitatif dan Kualitatif. Yogyakarta: Graha Ilmu.

Shaltout, M. (2016). Peda-Comical : A Personal Account of Comics in Education. Pedagogic Development, 6(2), 43-54. Retrieved from https://uobrep.openrepository.com/bitstream/h andle/10547/611799/319-847-1-

PB.pdf? sequence $=1$ \&isAllowed $=\mathrm{y}$

Sugiyono. (2010). Metode Penelitian Pendidikan Pendekatan Kuantitatif, Kualitatif, dan R\&D. Bangdung: Alfabeta.

Susilawati, Doyan, A., Artayasa, P., Soeprianto, H., \&
Harjono, A. (2021). Analysis of Validation Development Science Learning Tools using Guided Inquiry Model Assisted by Real Media to Improve the Understanding Concepts and Science Process Skills of Students. https://doi.org/10.29303/jppipa.v7i1.473

Wahyu, Y., Edu, A. L., \& Nardi, M. (2020). Problematika Pemanfaatan Media Pembelajaran IPA di Sekolah Dasar. Journal of Research in Science Education, $6(1)$, 107-112. https://doi.org/10.29303/jppipa.v6i1.344

Waluyanto, H. D. (2005). Komik sebagai Media Komunikasi Visual Pembelajaran. Nirmana, 7(1), 45-55. Retrieved from http:/ / 203.189.120.189/ejournal/index.php/dkv Larticle/viewFile/16441/16433

Wati, E. R. (2016). Ragam Media Pembelajaran. Jakarta: Kata Pena. 